\title{
Pemeriksaan Cea dan M2PK Sebagai Tes Skrining Pada Kanker Kolorektal
}

\author{
Evivana Pranika Murti ${ }^{1}$, Nuroh Najmi ${ }^{2 *}$, Apriani ${ }^{1}$, Rina Setyawati ${ }^{1}$ \\ ${ }^{1}$ Program Studi D III Teknologi Laboratorium Medis STIKes Kesetiakawanan Sosisal Indonesia \\ ${ }^{2 *}$ Departemen Oral Biologi, Fakultas Kedokteran Gigi Universitas Padjadjaran Bandung
}

\begin{abstract}
Abstrak
Kanker memiliki ciri mempertahankan sinyal proliferatif, menghindari penekan pertumbuhan, terjadi invasi dan metastasis, menginduksi angiogenesis, memungkinkan replikatif yang immortal, dan melawan kematian sel. Kanker kolorektal (CRC) merupakan hubungan kompleks dari sel tumor, sel non-neoplastik, dan sejumlah besar mikroorganisme. Deteksi dini pada awal lesi dapat menurunkan mordibitas dan mortilitas keganasan, sehingga penting dilakukan skrining. Pemeriksaan CEA dan M2PK dapat dilakukan sebagai tes skrining yang dilakukan di laboratorium. Beberapa Laboratorium sering kali hanya melakukan 1 pemeriksaan saja seperti CEA tanpa M2PK. Penelitian ini bertujuan untuk mengetahui perbedaan antara pemeriksaan CEA dan M2PK sebagai tes skrining kanker kolorektal. Penelitian ini dilakukan menggunakan metode komparatif. Penelitian dilakukan pada bulan Maret-Mei 2020 di Laboratorium Multilab Rawamangun. Sampel penelitian berasal dari 30 orang subjek yang dipilih berdasarkan kriteria harus melakukan pemeriksaan CEA dan M2PK secara bersamaan. Hasil uji statistik menggunakan uji Mann-Whitney diperoleh hasil p value 0,000. Hasil analisa tersebut menujukkan adanya perbedaan yang signifikan antara pemeriksaan CEA dan M2PK sebagai diagnosis kanker kolorektal. Pemeriksaan CEA dan M2PK dapat digunakan sebagai tes skrining awal pada pemeriksaan kanker kolorektal.
\end{abstract}

Kata kunci: Kanker Kolorektal, CEA, M2PK, Tes Skrining

\section{Cea And M2PK Examination As A Screening Test in Colorectal Cancer}

\begin{abstract}
The Hallmarks of cancer are sustaining proliferative signaling, evading growth suppressors, activating invasive and metastasis, inducing angiogenesis, enabling replicative immortality, resisting cell death. Colorectal cancer (CRC) is a complex association of tumor cells, non-neoplastic cells, and a large number of microorganisms. Early detection of lesions can reduce the morbidity and mortality of malignancy, so screening is important. CEA and M2PK examinations can be performed as screening tests carried out in the laboratory. Some laboratories often only carry out 1 examination such as CEA without M2PK. This study aims to determine the difference between CEA and M2PK as a colorectal cancer screening test. This research was conducted using a comparative method. The research was conducted in March-May 2020 at the Rawamangun Multilab Laboratory. The research sample came from 30 subjects who were selected based on the criteria that had to carry out CEA and M2PK examinations simultaneously. The results of statistical tests using the Mann-Whitney test obtained p-value 0.000. The results of the analysis showed that there was a significant difference between CEA and M2PK tests as a diagnosis of colorectal cancer. The CEA and M2PK tests can be used as initial screening tests for colorectal cancer.
\end{abstract}

Keywords: Colorectal Cancer, CEA, M2PK, Screening Test

Korespondensi: Nuroh Najmi, S.Si., M.Kes, Departemen Oral Biologi Fakultas Kedokteran Gigi, Universitas Padjadjaran Jl. Raya Bandung Sumedang; Jatinangor 45363, mobile 085795584997,

e-mail: nuroh@unpad.ac.id 


\section{Pendahuluan}

Kanker merupakan kelainan genetik yang disebabkan adanya mutasi DNA yang dapat diperoleh secara spontan atau dipengaruhi oleh lingkungan. Adanya perubahan genetik dan epigenetik ini dapat mengubah ekspresi atau fungsi dari suatu gen yang mengatur sel secara fundamental seperti pertumbuhan atau kematian sel (Kumar, 2013)

Kanker atau disebut juga neoplasia memiliki karakteristik sel pertumbuhan yang abnormal yang selalu aktif membelah. Pertumbuhan dari neoplasma cenderung tidak terkoordinasi dan relative otonom. Hal ini terjadi karena tidak memiliki control regulasi normal atas pertumbuhan dan pembelahan sel. Kanker memiliki ciri mempertahankan sinyal proliferatif, menghindari penekan pertumbuhan, terjadi invasi dan metastasis, menginduksi angiogenesis, memungkinkan replikatif yang immortal, dan melawan kematian sel (Hanahan \& Weinberg, 2011; Grossman \& Porth, 2014).

Sel normal terdapat proto onkogen yang berperan sebagai faktor kunci pengaturan proses biologis seperti sinyal faktor pertumbuhan, transduser seluler dan faktor transkripsi nuklir. Proto onkogen dapat berubah menjadi onkogen. Onkogen dapat terbentuk dan berperan dalam patogenesis kanker. Selain itu terdapat tumor suppressor gene yang berperan dalam pertumbuhan normal dan diferensiasi sel serta menghalangi perkembangan kanker (Kontomanolis et al., 2020). Kanker kolorektal (CRC) merupakan hubungan kompleks dari sel tumor, sel non-neoplastik, dan sejumlah besar mikroorganisme (Gagnière et al., 2016).

Kanker kolorektal merupakan kanker paling umum ketiga pada pria dan kedua pada wanita diseluruh dunia. Insidensi tertinggi ditemukan di Australia dan New Zealand, Eropa, Amerika Utara serta terendah ditemukan di Afrika dan wilayah Tengah dan Selatan Asia (Jemal et al., 2011). Frekuensi sakit kanker kolorektar antara wanita dan pria hampir sama dan lebih banyak terjadi pada usia 41 hingga 60 tahun (Permana et al., 2016)

Kanker kolorektal merupakan kanker yang dapat dicegah karena hampir selalu timbul dari neoplasma jinak dan dapat berkembang menjadi CRC dalam kurun waktu bertahun tahun (Grady et al., 2016). Pada perkembangan adenokarsinoma kolorektal sel epitel mengalami mutasi sekuensial genetik dan epigenetik pada onkogen atau tumor suppressor gene yang spesifik dan menyebabkan proliferasi serta pembaharuan diri. Sel epitel yang normal akan berubah menjadi hiperproliferatif dan menjadi neoplasma jinak (De Rosa et al., 2015).

Skrining merupakan suatu proses deteksi suatu penyakit yang bertujuan untuk meningkatkan kesadaran pencegahan serta diagnosis dini. Apabila seseorang ditemukan positif setelah dilakukan tes skrining maka perlu dirujuk ke dokter serta melakukan suatu pengobatan (Maulani., 2019). Tes skrining pada individu dengan resiko rata-rata dapat menurunkan kejadian CRC dan mortalitas. Beberapa negara menetapkan panduan dalam penetapan metode skrining hanya saja baku emas tetap kolonoskopi. Seperti menurut National Comprehensive Cancer rekomendasi skrining termasuk kolonoskopi setiap 10 tahun, gFOT (fecal occult blood testing) sensitivitas tinggi dan FIT (fecal immunochemical test), dan sDNA setiap 3 tahun (Bénard et al., 2018) .

Deteksi dini pada stadium awal lesi dapat menurunkan morbiditas dan mortalitas keganasan. Selain itu untuk membantu diagnosis, diperlukan pemantauan penanda atau marker yang tidak invasif untuk mendeteksi kanker rektum lebih awal. Tes skrining sangat berguna untuk mengetahui kanker kolorektal secara dini sehingga bisa diberikan penanganan cepat dan tepat, yang meliputi riwayat medis, pemeriksaan fisik, pemeriksaan darah lengkap, enzim hati, penanda tumor, colononoscopy, biopsy, Gene test, MSI testing, CT Scan, USG, MRI, X-Ray, PCT Scan dan angiography. Baku emas deteksi dini polip usus/kanker adalah kolonoskopi invasif, tetapi biayanya tinggi, sedangkan penanda tumor CEA dan M2PK relatif lebih murah sehingga menjadi pilihan yang baik untuk mendeteksi polip dini/kanker (Tonus et al., 2012)

C Protein biomarker berbasis darah telah banyak digunakan utnuk diagnostik kanker kolorektal. CEA memiliki sensitivitas tinggi diantara penanda tunggal lai seperti CA19-9, ferritin, atau CA125 (Gao et al., 2018). Carcinoembryonic antigen (CEA) tidak seacra normal diproduksi dalam jumlah signifikasn saat lahir tetapi akan meningkat pada kanker kolorektal (Hall et al., 2019). CEA dan CA19-9 merupakan metode deteksi yang dapat digabung sehingga dapat membantu meningkatkan akurasi evaluasi prognosis CRC (Xu et al., 2019). Pada pasien kanker kolorektal peningkatan kadar CEA ata CA19-9 dapat dijadikan penanda adanya perkembangan tumor, sedangkan tidak ada peningkatan dapat dijadikan penanda adanya pengendalian penyakit (Jia et al., 2019). 
Tes M2PK adalah penanda tumor untuk deteksi awal dari polip yang dapat menjadi awal kanker kolorektal. Enzim biomarker M2PK telah diidentifikasi sebagai enzim kunci pada kanker kolorektal dan polip. Tes M2PK mampu mendeteksi 80,3\% kanker kolorektal (Tonus et al., 2012). M2PK menggunakan feses sebagai sampel pemeriksaan. Pemeriksaan dengan M2PK , CEA dan CA19-9 terlihat memiliki kadar yang berbeda pada pasien kolonik polip menjadi kanker kolorektal. Hasil M2PK dapat membedakan pasien dengan kanker kolorektal atau polip. Pasien dengan M2PK $>25$ atau M2PK $\leq 25$ dan CA19-9> 25 menderita probabilitas CRC yang lebih tinggi (Dabbous et al., 2018). Beberapa fasilitas kesehatan menerapkan hanya 1 metode skrining kanker kolorektal seperti CEA saja tanpa pemeriksaan lainnya. Berdasarkan hal tersebut maka penelitian ini perlu dilakukan untuk mengetahui perbedaan antara pemeriksaan CEA dan M2PK pada pasien yang didiagnosis memiliki penyakit kanker kolorektal.

\section{Metode}

Penelitian ini dilakukan dengan metode komparatif yang bertujuan untuk membedakan pemeriksaan CEA dan M2PK sebagai diagnosis kanker kolorektal. Penelitian ini dilaksanakan pada bulan Maret - Mei 2020 di Laboratorium Multilab Rawamangun Jakarta. Proses pengambilan sampel yang digunakan dalam penelitian adalah metode purposive sampling dengan kriteria inklusi pasien yang melakukan pemeriksaan CEA dan M2PK secara bersamaan di Laboratorium Multilab periode Maret - Mei 2020. Penelitian ini sudah mendapatkan ijin dari pihak laboratorium dan peneliti menjamin kerahasiaan data hasil penetitian. Pada penelitian ini bahan yang digunakan adalah serum dan feses. Alat yang digunakan pada penelitian ini adalah Enzyme Linked Immunosorbent Assay (ELISA), fotometer Rayto, shaker, rocking platform, mikropipet, rak tabung, tips kuning dan biru, 1 kit reagen CEA dan 1 kit reagen M2PK. Analisis data menggunakan uji statistik MannWhitney.

\section{Hasil}

Berdasarkan hasil penelitian yang dilakukan Maret - Mei 2020 didapatkan sample dari 30 subjek yang melakukan pemeriksaan CEA dan M2PK bersamaan, hasil tersebut disajikan pada Tabel 1. Hasil pemeriksaan dengan M2PK memiliki nilai rata rata lebih tinggi dibandingkan dengan CEA.

Tabel 1. Hasil Perhitungan CEA dan M2PK

\begin{tabular}{lcc}
\hline \multicolumn{1}{c}{ Variabel } & $\begin{array}{c}\text { CEA } \\
\text { ng/mL }\end{array}$ & $\begin{array}{c}\text { M2PK } \\
\text { U/mL }\end{array}$ \\
\hline Rata-rata & 1,76 & 11,8 \\
\hline Std. Deviasi & 1,27 & 11,41 \\
\hline Minimum & 0,50 & 1,3 \\
\hline Maksimum & 6,90 & 40,1 \\
\hline
\end{tabular}

Tabel 1 menunjukkan hasil deskriptif dari hasil penelitian pemeriksaan kadar CEA dan M2PK. Dari data tersebut didapatkan nilai ratarata CEA $1,76 \mathrm{ng} / \mathrm{mL}$ dan M2PK 11,8 U/mL. Nilai M2PK lebih tinggi dibandingkan dengan hasil CEA. Hasil penelitian ini sesuai dengan hasil penelitian dari Wen Meng et al (2012) tentang Serum M2-piruvat kinase yaitu biomarker non-invasif yang menjanjikan untuk skrining massa kanker kolorektal yang menyatakan bahwa M2PK memiliki nilai diagnosis sedang hingga tinggi untuk kanker kolorektal tahap awal dan lanjutan. Tetapi pada CEA memiliki nilai diagnosis rendah hingga sedang untuk semua tahap kanker kolorektal (Meng et al, 2012; Tonus et al., 2012). Hasil penelitian berdasarkan Tabel 2. menjelaskan sebaran hasil pemeriksaan CEA dan M2PK.

Tabel 2. Sebaran Hasil Pemeriksaan CEA dan M2PK

\begin{tabular}{lcccc}
\hline \multirow{2}{*}{ Kadar } & \multicolumn{2}{c}{ CEA } & \multicolumn{2}{c}{ M2PK } \\
\cline { 2 - 5 } & $\mathbf{N}$ & $\boldsymbol{\%}$ & $\mathbf{N}$ & $\boldsymbol{\%}$ \\
\hline Normal & 29 & $97 \%$ & 10 & $30 \%$ \\
\hline Meningkat & 1 & $3 \%$ & 20 & $70 \%$ \\
\hline
\end{tabular}

Hasil penelitian menunjukkan pada pemeriksaan serum didapatkan hasil kadar CEA normal $97 \%$ dan 3\% mengalami peningkatan sedangkan pemeriksaan M2PK pada feses didapatkan hasil kadar M2PK normal 30\% dan $70 \%$ mengalami peningkatan. Hasil yang meningkat ini menunjukkan adanya suatu hasil penegakkan diagnosis pada kanker kolorektal. Sensitivitas M2PK lebih tinggi tetapi spesifitas M2PK lebih rendah dibandingkan dengan CEA (Meng, 2012). Data hasil penelitian didapatkan hasil yang bervariasi, pada pasien dengan kadar CEA normal didapatkan hasil kadar M2PK yang meningkat tetapi pada pasien lain didapatkan hasil kadar M2PK yang normal. Pemeriksaan kanker kolorektal dengan M2PK dengan sampel feses atau plasma tidak terdapat perbedaan. Hanya terlihat berbeda hasil pada 
pasien kanker yang merokok tau tidak (Rigi et al., 2020). Sedangkan untuk pasien dengan kadar CEA meningkat kadar M2PK juga meningkat.

Tabel 3. Distribusi Pasien Berdasarkan Jenis Kelamin

\begin{tabular}{lcc}
\hline Jenis Kelamin & Frekuensi & Persentase (\%) \\
\hline Laki laki & 17 & 57 \\
\hline Perempuan & 13 & 47 \\
\hline Jumlah & 30 & 100 \\
\hline
\end{tabular}

Pada tabel 3 menunjukkan frekuensi terbanyak jenis kelamin laki laki dibandingkan dengan perempuan. Selain itu pada tabel 4 menunjukkan hasil bahwa pasien terbanyak berada pada usia lebih dari 50 tahun.

Tabel 4. Distribusi Frekuensi Berdasarkan Usia

\begin{tabular}{lcc}
\hline Usia (tahun) & Frekuensi & Persentase (\%) \\
\hline$<40$ & 7 & 23 \\
\hline $40-50$ & 5 & 17 \\
\hline$>50$ & 18 & 60 \\
\hline Jumlah & 30 & 100 \\
\hline
\end{tabular}

Rata rata usia resiko kanker kolorektal yang harus menjalani tes skrining adalah usia 50 hingga 75 tahun. Akan tetapi pada orang Afrika Amerika skrining direkomendasikan dimulai pada usia 45 tahun (Bénard et al., 2018).

Penelitian yang dilakukan oleh Dabbous et al. (2018) menjelaskan usia pasien kanker kolorektal berada pada rata rata rentang usia 29 hingga 67 tahun dengan riwayat medis tertinggi yaitu merokok dan penyakit diabetes mellitus. Laki laki mendominasi pada data yang dijelaskan oleh Dabbous et al. (2018), serta rata rata pasien memiliki gejala rata rata tertinggi memiliki manifestasi anemia, konstipasi, serta penurunan berat badan (Dabbous et al., 2018). Meskipun demikian Permana et al. (2016) memaparkan bahwa frekuensi sakit kanker kolorektar antara wanita dan pria hampir sama (Permana et al., 2016).

Pada penelitian ini dilakukan analisis dengan Mann-Whitney untuk melihat perbedaan pemeriksaan CEA serta M2PK pada pemeriksaan kanker kolorektal, dapat dilihat pada Tabel 3. Data hasil penelitian tidak berdistribusi dengan normal sehingga data dianalisis dengan analisis non-parametrik diperoleh nilai $\mathrm{P}$ value : $0,000(\mathrm{P}<0,05)$.
Tabel 5. Hasil Uji Mann-Whitney

\begin{tabular}{lcc}
\hline \multicolumn{1}{c}{ Variabel } & $\begin{array}{c}\text { Asym Sig } \\
(2 \text { tailed })\end{array}$ & Kriteria \\
\hline $\begin{array}{l}\text { Kadar CEA \& } \\
\text { M2PK }\end{array}$ & 0,000 & Ada perbedaan \\
\hline
\end{tabular}

Hasil penelitian menunjukkan terdapat perbedaan hasil pemeriksaan CEA dan M2PK sebagai diagnosis kanker kolorektal. Penelitian ini sejalan dengan penelitian yang dilakukan oleh Wen Meng et al. (2012) hasil penelitiannya menunjukan pemeriksaan M2PK dengan sensitifitas tinggi dapat mencapai nilai diagnostik tinggi dalam mendeteksi kanker kolorektal dan adenoma lanjut dan lebih unggul daripada pemeriksaan CEA. Akan tetapi penelitian lain melaporkan bahwa kadar CEA dan kadar albumin tidak berhubungan dengan lokasi tumor pada kanker kolorektal (Permana et al., 2016). Pemeriksaan M2PK berperan penting dalam mengurangi biaya, ketidaknyamanan dan komplikasi terkait kolonoskopi selama skrining kanker kolorektal. Pemeriksaan M2PK dapat digunakan sebagai tes skrining yang efisien sebagai tes skrining kanker kolorektal dan memiliki sensitifitas yang tinggi dibandingkan dengan CEA. Akan tetapi pemeriksaan M2PK tidak dijadikan baku emas untuk diagnosis kanker kolorektal karena pemeriksaan M2PK tes darah maupun feses hanya dapat memberikan indikasi kuat akan kehadiran kanker kolorektal, sedangkan kolonoskopi sebagai baku emas adalah tes yang paling akurat untuk diagnosis kanker kolorektal karena merupakan pemeriksaan yang dilakukan pada seluruh bagian usus besar. Tes kolonoskopi memiliki sensitivitas tinggi pada deteksi massa dan polip pada rektal atau kolon. Semua pasien CRC memiliki massa rektal dan kolon (Dabbous et al., 2018).

Pemeriksaan kanker kolorektal dengan M2PK dapat dilakukan pada sampel darah dan feses. Pemeriksaan dengan sampel feses memiliki tingkat akurasi yang tinggi pada pemeriksaan M2PK secara cepat. Akan tetapi nilai sensitivitas kanker proksimal lebih rendah dibandingkan dengan kanker distal (Sithambaram et al., 2015). Pada pemeriksaan plasma M2PK tidak ditemukan perbedaan signifikan antara konsentrasi M2PK pada jenis tumor yang berbeda. Tumor plasma M2PK bukan penandan spesifik untuk kanker kolorektal dan banyak ditemukan pada jenis kanker lain termasuk kanker payudara, paruparu, ovarium dan tiroid (Muñoz-Colmenero et al., 2015). 
Pemeriksaan M2PK dijadikan sebagai tes pemeriksaan dini dan terlihat hasil perbedaan yang siginifikan antara kasus kanker kolon dengan orang sehat. Kanker usus besar dapat dideteksi dengan fecal M2PK dengan spesifitas, sensitivitas dan akurasi lebih dari $90 \%$. Pemeriksaan fecal M2PK dapat dijadikan pemeriksaan skrining untuk kasus kanker kolon (Ibrahim et al., 2018). Kadar CEA pada pemeriksaan CEA kanker kolorektal akan meningkat seiring dengan tingginya stadium kanker kolorektal. Pasca operasi kadar CEA akan mengalami penurunan. Pada stadium 1 sudah mengalami pertumbuhan di usus besar akan tetapi belum menyebar. Stadium 2 kanker telah menyebar diseluruh dinding usus besar bahkan menembus dinding usus besar. Stadium 3 kelenjar getah bening yang berdekatan dengan usus besar telah diserang oleh sel kanker. Pada stadium 4 kanker kolon telah menyebar ke organ lain seperti paru-paru dan hati (Widyasari et al., 2018).

Penelitian tentang pemeriksaan CEA dan M2PK sebelumya banyak dilakukan di Indonesia khususnya di Jakarta belum ditemukan. Rumah sakit maupun laboratorium lebih banyak menggunakan pemeriksaan CEA dan tes darah samar feses untuk diagnosis kanker kolorektal, sehingga penelitian tentang pemeriksaan CEA dan M2PK belum dilakukan. Pada penelitian sebelumnya membedakan pemeriksaan M2PK dengan CEA dan penanda tumor yang lain jadi tidak secara spesifik membedakan pemeriksaan CEA dan M2PK. Pemeriksaan CEA dan M2PK adalah pemeriksaan yang dianjurkan untuk deteksi polip dini dan kanker kolorektal karena biayanya relatif murah meskipun baku emas pemeriksaanya adalah kolonoskopi invasif.

Kesimpulan hasil penelitian ini terdapat perbedaan signifikan antara pemeriksaan kanker kolorektal menggunakan CEA dan M2PK. Pemeriksaan menggunakan CEA dan M2PK dapat dijadikan pemeriksaan skrining yang saling melengkapi karena masing masing memiliki tingkat sensitivitas dan spesifitas.

\section{Ucapan Terima Kasih}

Peneliti mengucapkan terima kasih kepada pihak Laboratorium Multilab Rawamangun Jakarta yang telah memberikan kesempatan untuk melakukan penelitian.

\section{Daftar Pustaka} review of colorectal cancer screening guidelines for average-risk adults: Summarizing the current global recommendations. 24(1), 124-138. https://doi.org/10.3748/wjg.v24.i1.124

Dabbous, H. K., Mohamed, Y. A. E., El-folly, R. F., \& El-talkawy, M. D. (2018). Evaluation of Fecal M2PK as a Diagnostic Marker in Colorectal Cancer.

De Rosa, M., Pace, U., Rega, D., Costabile, V., Duraturo, F., Izzo, P., \& Delrio, P. (2015). Genetics, diagnosis and management of colorectal cancer (Review). Oncology Reports, 34(3), 1087-1096. https://doi.org/10.3892/or.2015.4108

El, M., Ibrahim, T., Mohamed, M. A., Elawady, M. A., \& Hala, A. (2018). The Fecal M2PK As A Novel Biomarker for Screening of Cancer Colon. The Egyptian Journal of Community Medicine, 36(3), 93-102. https://doi.org/10.21608/ejcm.2018.1633 7

Gagnière, J., Raisch, J., Veziant, J., Barnich, N., Bonnet, R., Buc, E., Bringer, M. A., Pezet, D., \& Bonnet, M. (2016). Gut microbiota imbalance and colorectal cancer. World Journal of Gastroenterology, 22(2), 501-518. https://doi.org/10.3748/wjg.v22.i2.501

Gao, Y., Wang, J., Zhou, Y., Sheng, S., Qian, S. Y., \& Huo, X. (2018). Evaluation of Serum CEA, CA19-9, CA72-4, CA125 and Ferritin as Diagnostic Markers and Factors of Clinical Parameters for Colorectal Cancer. Scientific Reports, 8(1), $\quad 1-9$. https://doi.org/10.1038/s41598-01821048-y

Grady, W. M., Markowitz, S. D., \& Hutchison, F. (2016). potential application to colorectal cancer screening. 60(3), 762772. https://doi.org/10.1007/s10620-0143444-4.The

Hall, C., Clarke, L., Pal, A., Buchwald, P., Eglinton, T., Wakeman, C., \& Frizelle, F. (2019). A review of the role of carcinoembryonic antigen in clinical 
practice. Annals of Coloproctology, 35(6), 294-305. https://doi.org/10.3393/ac.2019.11.13

Hanahan, D., \& Weinberg, R. A. (2011). Hallmarks of cancer: The next generation. Cell, 144(5), 646-674. https://doi.org/10.1016/j.cell.2011.02.013

Janosik, S. M. (2014). Porth's Pathophysiology. In Lippincott Williams \& Wilkins (Vol. 42, Issue 4).

Jemal, A., Bray, F., \& Ferlay, J. (2011). Global Cancer Statistics. 61(2), 69-90. https://doi.org/10.3322/caac.20107.Avail able

Jia, J., Zhang, P., Gou, M., Yang, F., \& Qian, N. (2019). The Role of Serum CEA and CA19-9 in Efficacy Evaluations and Progression-Free Survival Predictions for Patients Treated with Cetuximab Combined with FOLFOX4 or FOLFIRI as a First-Line Treatment for Advanced Colorectal Cancer. 2019.

Kontomanolis, E. N., Koutras, A., Syllaios, A., Schizas, D., Mastoraki, A., Garmpis, N., Diakosavvas, M., Angelou, K., Tsatsaris, G., Pagkalos, A., Ntounis, T., \& Fasoulakis, Z. (2020). Role of oncogenes and tumor-suppressor genes in carcinogenesis: A review. Anticancer Research, 40(11), 6009-6015. https://doi.org/10.21873/anticanres.14622

Grossman, S.C., Porth, C.M. (2014). Porth's Pathophysiology Concepts of Altered Health States $9^{\text {th }}$ Ed. Lippincot Wiliams and Wilkins.

Maulani, J. (2019). Aplikasi Kesehatan Menggunakan Metode Epidemiologi Skrining Tes Untuk Karyawan Cv.Annisa. Technologia, 10(1).

Meng, W. (2012). Serum M2-pyruvate kinase: A promising non-invasive biomarker for colorectal cancer mass screening. World Journal of Gastrointestinal Oncology, 4(6), 145. https://doi.org/10.4251/wjgo.v4.i6.145

Muñoz-Colmenero, A., Fernández-Suárez, A., Fatela-Cantillo, D., Ocaña-Pérez, E., Domínguez-Jiménez, J. L., \& Díaz-
Iglesias, J. M. (2015). Plasma tumor M2pyruvate kinase levels in different cancer types. Anticancer Research, 35(7), 42714276.

Permana, F., Budiono, B., \& Farida, H. (2016). Hubungan Kadar Carcinoembryonic Antigen (Cea) Dan Albumin Serum Dengan Lokasi Kanker Kolorektal Studi Kasus Di Rsup Dr. Kariadi. Diponegoro Medical Journal (Jurnal Kedokteran Diponegoro), 5(4), 808-816.

Rigi, F., Jannatabad, A., Izanloo, A., Roshanravan, R., Hashemian, H. R., \& Kerachian, M. A. (2020). Expression of tumor pyruvate kinase M2 isoform in plasma and stool of patients with colorectal cancer or adenomatous polyps. BMC Gastroenterology, 20(1), 1-7. https://doi.org/10.1186/s12876-02001377-x

Schrijvers, D., Aapro, M., Zakotnik, B., Audisio, R., van Halteren, H., \& Hurria, A. (2010). ESMO handbook of cancer in the senior patient. ESMO Handbook of Cancer in the Senior Patient, iii-193. https://doi.org/10.3109/9781841847481

Sithambaram, S., Hilmi, I., \& Goh, K. L. (2015). The diagnostic accuracy of the M2 pyruvate kinase Quick stool test-A rapid office based assay test for the detection of colorectal cancer. PLoS ONE, 10(7). https://doi.org/10.1371/journal.pone.0131 616

Tonus, C., Sellinger, M., Koss, K., \& Neupert, G. (2012). Faecal pyruvate kinase isoenzyme type M2 for colorectal cancer screening: A meta-analysis. World Journal of Gastroenterology, 18(30), 4004-4011.

https://doi.org/10.3748/wjg.v18.i30.4004

Vinay Kumar, Abdul K Abbas, J. C. A. (2013). Robbins Basic Pathology (9th ed.). ElsevierSaunders.

Widyasari, A., Tambunan, B.A., Budipramana, V. (2018). The Role Of Carcinoembryonic Antigen In Assessing The Success Of Surgical Treatment In Colorectal Cancer Based On Staging. Jurnal Indonesia, 21(3), 261-265. 
http://journal.unair.ac.id/download-

fullpapers-IJCPML-12-3-08.pdf

Xu, X., Niu, M., Zhang, B., Chang, J., Su, F., \& Wang, K. (2019). Clinical value of CEA and CA19-9 in colorectal cancer by Kaplan-Meier survival curve. 12(12), 13305-13310. 